DIW BERLIN

Discussion

Papers

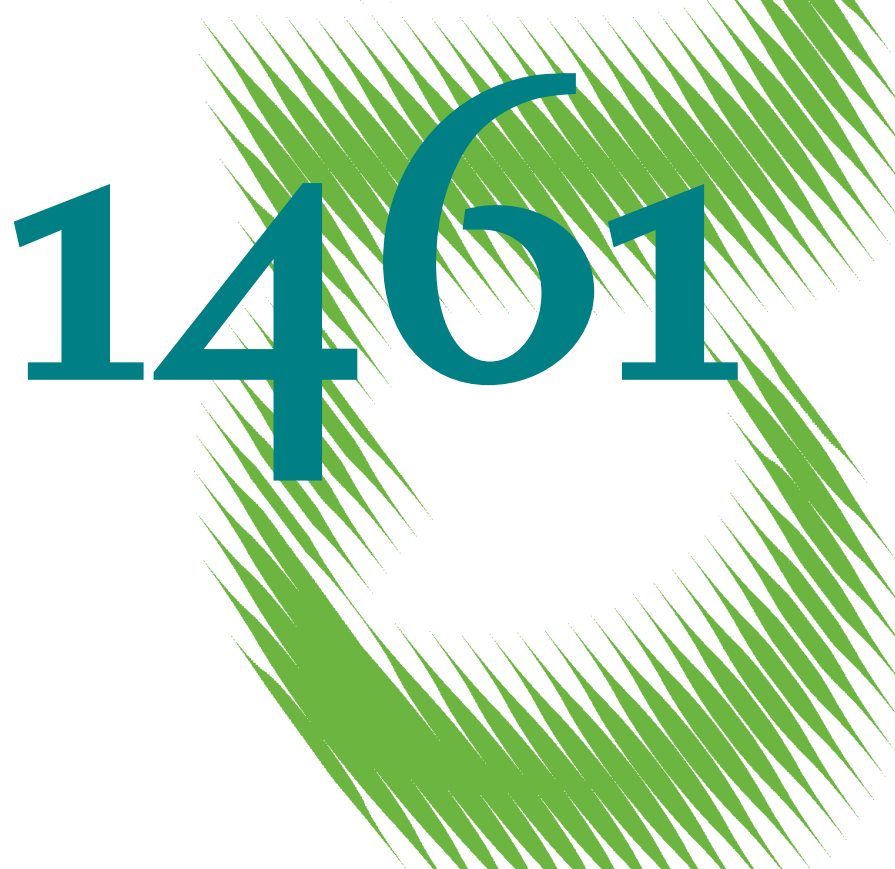

The Impact of South-South Trade Agreements on FDI 
Opinions expressed in this paper are those of the author(s) and do not necessarily reflect views of the institute.

IMPRESSUM

(C) DIW Berlin, 2015

DIW Berlin

German Institute for Economic Research

Mohrenstr. 58

10117 Berlin

Tel. +49 (30) $89789-0$

Fax +49 (30) $89789-200$

http://www.diw.de

ISSN electronic edition 1619-4535

Papers can be downloaded free of charge from the DIW Berlin website:

http://www.diw.de/discussionpapers

Discussion Papers of DIW Berlin are indexed in RePEc and SSRN:

http://ideas.repec.org/s/diw/diwwpp.html

http://www.ssrn.com/link/DIW-Berlin-German-Inst-Econ-Res.html 


\title{
The Impact of South-South Trade Agreements on FDI
}

\section{Mondher Cherif}

\author{
Christian Dreger ${ }^{1}$
}

\begin{abstract}
The integration of emerging markets into the global economy is heavily promoted by foreign direct investment (FDI) inflows. Within the factors driving the location of FDI, regional trade agreements (RTAs) become increasingly relevant for emerging markets. We explore the impact of South-South trade agreements on FDI by dynamic panel models. The MENA countries are compared to the better performing regions in Latin America and Southeast Asia. Several striking results emerge from the analysis. First, agglomeration effects are weaker for the MENA region. Second, the impact of the RTA is important. However, RTAs do not generally rise the attractiveness of the region for foreign investors, as the effect interacts with business-friendly regulations. Third, financial deepening in the host country is a crucial factor, often again in combination with the institutional framework. Furthermore, institutional conditions may not be relevant per se, but only in terms of its interaction with the macroeconomic determinants.
\end{abstract}

JEL Code: F15, F21, F63, E22

Keywords: MENA Region, foreign investment, South-South trade agreements

${ }^{1}$ Cherif: Université de Reims Champagne-Ardenne, Laboratoire Regards, France, mondher.cherif@univ-reims.fr Dreger: DIW Berlin, Germany, cdreger@diw.de. 

Foreign direct investment (FDI) is crucial for catching up growth in emerging markets and their smoothed integration into the world economy. With a share of around 10 percent, FDI accounts for a huge part of gross capital formation in emerging markets. FDI fosters the modernization of industries and can contribute to GDP growth even more than domestic investment (Borensztein, De Gregorio and Lee, 1998). By initiating spillovers through the diffusion of new technologies and management skills, FDI can raise total investment in the host economy more than one for one. The impact may be restricted by insufficient absorption capacities, i.e. technological backwardness or a low qualified labour force in the recipient country, see De Mello (1997). The actual size of the FDI multiplier depends on the degree of complementarity and substitution between FDI and local investment. Crowding out effects can occur especially in the short run, if domestic firms are unable to compete with more advanced foreign companies (Markusen and Venables, 1997). Often, they operated under sheltered trade regimes before (Agosin and Machado, 2005). The net effect is also shaped by the institutional conditions in the host country. By imposing regulations like local content requirements, policies might affect the industrial structure and can influence the transition towards market based economies (Kumar, 2002).

-Figure 1 and Table 1 about here-

Due to an increase in the risk aversion of foreign investors, FDI dropped sharply during the financial crisis. FDI recovered afterwards, but the development was unequal across the world economy. While FDI inflows to industrial countries are still 50 percent below their pre-crisis level, flows into developing countries exceed their 2007/08 benchmark by 15 percent. In fact, emerging markets have overtaken the developed world as a primary destination for FDI in the recent years (Figure 1). In terms of the flows emerging markets receive 60 percent of the global level, while the stocks are almost at 40 percent. Developing countries in Latin America and Southeast Asia are the primary destinations. FDI stocks amount to 20 and 45 percent, respectively, measured relative to emerging market stocks. In contrast, the Middle East and North African (MENA) countries did not benefit from the recovery. FDI inflows amount to 60 percent of the pre-crisis level, and this share has been fairly constant over the recent years. The region 
receives only 3 percent of the total inflows to emerging markets. However, compared to GDP, the FDI stock is even larger than in other areas (Table 1). Eventually, foreign capital is used less efficiently in the MENA region, probably due to shortages in human capital or poor financial markets (Alfaro, Kalemli-Ozcan and Sayek, 2009). Unveiling the reasons of why some countries are more successful than others is important for policy advice, especially in the capital-starved countries.

This paper provides comprehensive evidence on the determinants of FDI in emerging markets and the role of regional trade agreements (RTAs) therein. To foster catching up growth, countries are engaged in trade agreements, both within the region (South-South) and between them and industrial countries (North-South). These agreements are seen as catalysts to improve the competitiveness of domestic sectors by promoting capital inflows. Led by emerging Asia and Latin America, South-South trade doubled over the last two decades and amounts to 25 percent of current global trade. The vast acceleration in trade might have contributed to the increase of FDI to many emerging markets. As FDI from industrial to developing countries might be guided by distinct motives such as the access to natural resources, evidence is based on South-South trade agreements. In particular, the AGADIR, MERCOSUR, and AFTA agreements are considered as potential drivers of FDI. The development in the MENA countries is of specific relevance. Demographic pressure and labour force expansion led to high unemployment rates and slow growth in terms of per capita income in many parts of the region. Fostering economic growth cannot only increase economic welfare but might also encourage domestic reforms, which can in turn reduce emigration and tame extremist sentiments threatening global security.

Despite the huge evidence on FDI, gaps in the literature are still striking. First, most papers focus on Latin America and Southeast Asia. Only a handful refer to MENA countries. The Gulf states and Iran are often included in these studies. However, factors driving FDI are different for oil-exporting countries, i.e. evidence based on mixed panels might be biased. Besides that, the role of RTAs is usually neglected. Second, a comprehensive analysis of FDI in emerging markets is presented. In addition to the MENA countries, Latin America and Southeast Asia are included as a reference. Since these regions have shown a much better performance, potential impediments in the MENA region might become more transparent in this setting. Third, many studies are based on cross section regressions. By adding the time series dimension, one can control for dynamic effects, persistence and endogeneity. Several striking results emerge from the analysis. The results suggest that agglomeration effects are weaker for the MENA region. 
Second, the impact of the RTA is important. However, as can be seen in case of the Mena region, RTAs do not generally rise the attractiveness of the region for foreign investors. Third, financial deepening in the host country matters, often again in combination with the framework conditions. The institutional design may not be relevant per se, but only in terms of its interaction with the macroeconomic determinants. Thus, the implementation of more business-friendly institutions remains a challenging task for policymakers.

The rest of the paper is organized as follows. Section 2 discusses how regional integration can potentially affect FDI, in addition to the standard determinants. RTAs are reviewed in Section 3. Section 4 presents the econometric approach and provides a discussion of the results. Section 5 concludes with policy implications.

\section{$2 \quad$ Locational decisions of multinational firms}

According to the IMF manual of the Balance of Payments, FDI is an investment made to acquire long lasting control over an enterprise operating in a foreign country. The purpose of the investor is to gain an effective voice in the management. A threshold of 10 percent of the company shares is usually seen as the minimum to exert significant influence on foreign firm decisions. Following Dunning and Lundan (2008) the reasons for being engaged in foreign investment can be classified into four categories: the seek of natural resources, markets, efficiency and strategic assets. The need for safe access to natural resources may explain much of early FDI flows, mainly from industrialised countries to developing, but often resource-rich economies. The market seeking motive is directed to improve the presence in international markets. The purpose of efficiency FDI is to take advantage of different factor endowments and institutional conditions in several countries. In a globalized world, they can lead to a reallocation of production across regions. FDI in strategic assets involves the acquisition of knowledge-based resources with the aim to transform the core competency of the investor and his competitive position.

As a rule, the benefits of going multinational must compensate for the costs of operating abroad. FDI may be of the horizontal or vertical type, see Navaretti and Venables (2006). Horizontal multinationals produce the same goods and services in different countries. They invest abroad to avoid trade costs (transport, tariffs and quotas etc) associated with exports from the home location to the foreign market. If the host country is small, the potential savings in trade costs are insufficient to offset the fixed costs of setting up production facilities there; hence, 
exports might be chosen instead of FDI to serve the market abroad. Bigger market size of the host country, lower plant level fixed costs and larger trade costs are more conducive to horizontal FDI.

In contrast, vertical multinationals allocate different stages of the production chain to different places to reduce overall costs. Vertical FDI likely arises when countries have unequal factor endowments and factor prices. For example, a vertical multinational may pursue R\&D and skill intensive activities in skill abundant countries, while unskilled labour intensive stages are shifted to unskilled labour abundant countries. The trade-off for vertical multinationals is between lower costs of producing abroad and trade costs to export the products to the sales market. Trade and FDI are substitutes in the horizontal case, but complements when FDI is vertical. Low trade costs should discourage horizontal FDI but encourage vertical FDI. Note that this does not necessarily imply that a decline in trade costs will reduce the weight of horizontal in total FDI. If costs fall due to the removal of trade barriers in a RTA, outside firms invest in one country to serve the entire trade block. By integrating both variants as special cases in a general equilibrium model with international fragmented production and different factor endowments, Markusen and Maskus (2002) found support for the horizontal model and rejected the vertical alternative.

From the variety of determinants potentially affecting FDI, the market size effect appears to be the most robust, i.e. larger countries receive higher FDI (Chakrabarti, 2001). Other candidates, such as labour costs, openness to trade, or exchange rates have been widely discusssed in the literature, but the findings are controversial. See Blonigen (2005) for a recent survey of empirical findings. In principle, lower labour costs in the host relative to the home country can attract investments seeking for efficiency, i.e. the effect of labour costs on FDI should be negative, see Bevan and Estrin (2004), among others. Similarly, Braconier, Norbaeck and Urban (2005) found that countries where less-skilled labour is relatively cheap can acquire more resources. However, there might be also a multinational wage premium, as wages offered by foreign companies often exceed the domestic level (Aitken and Harrison, 1999). Furthermore, wages reflect labour quality and productivity. If foreign investors demand higher skills, the overall effect on FDI can turn to be positive. In fact, numerous studies reported that better human capital will stimulate FDI (Noorbakhsh, Paloni and Yousef, 2001). The impact of openness is also not clear on a priori grounds. Openness to trade can be important as multinational firms pursue increasingly complex integration strategies that require the unrestricted exchange of intermediate goods at all stages of the production process. Indeed, several authors reported a positive rela- 
tionship between openness and FDI, although it might be restricted to some industrial sectors, such as manufacturing (Wheeler and Mody, 1992). But a direction of causality is not implied. Efficiency seeking FDI boost exports and openness, implying that endogeneity problems can occur. Besides that, the results might be subject to measurement error: Countries with larger domestic markets tend to be less open, since foreign trade to GDP ratios are often taken as a proxy for openness.

Many authors argued that an appreciation of the home currency can raise FDI to the host country, see for example Froot and Stein (1991) and Klein and Rosengren (1994). To the extent that firms at home hold more of their wealth in own currencies, a depreciation of the host currency raises their relative wealth position and lowers the relative capital cost. Hence, investors seek more aggressively for assets abroad. Note that the argument relies on imperfect capital markets. Otherwise, arbitrage will prevent the existence of persistent differences of the risk-adjusted expected returns across countries. Moreover, investors do not expect a further depreciation after the investment is made. In recent years, quantitative easing policies in the industrial states contributed to huge capital inflows in developing countries. Their reversal may cause a decline of FDI, leading to a depreciation of emerging market currencies. In addition, high volatile exchange rates can deter FDI. The increase in risk reduces the certainty equivalent of the exchange rate, and lowers expected profits from FDI. This is particularly relevant if production structures are quite inflexible, i.e. if FDI projects represent huge sunk costs (Aizenman, 1992).

Besides the macroeconomic factors, institutional conditions in the host countries can be decisive to attract FDI, see Wei (2000) and Luo (2009). For example, weak legal protection of assets increases the risk of expropriation. Lee and Mansfield (1996) found a positive relationship between FDI and the protection of intellectual property rights. Habib and Zurawicki (2002) reported a negative influence of corruption on FDI, as it can lead to operational inefficiencies. Payments to host country officials increase the cost of doing business when compared to a more competitive market. Drabek and Payne (2001) provided evidence on a negative impact of non-transparency, i.e. a composite measure based on corruption, unstable economic policies, weak protection of property rights and poor governance on FDI. Institutional quality, the absence of internal conflicts as well as ethnic tensions and political stability can play an independent role, but may also interact with the macroeconomic environment. For example, openness to trade might be crucial to FDI, but only in countries with sound institutions. Globermann and Shapiro (2003) stressed the role public goods to stimulate FDI. 
The implementation of RTAs affects the regulatory framework under which international investors operate (Blomström and Kokko, 1997). While potential direct effects may be related to parallel changes in the investment rules associated with the RTA, indirect effects can occur due to trade liberalisation. As RTAs combine formerly fragmented markets to a more homogenous one, the market size is affected. Efficiency gains are expected due to the exploitation of comparative advantage and intensified competition in the integrated area. The larger market size generates economies of scale. Baltagi, Egger and Pfaffermayr (2007) emphasized the relevance of third-country effects for FDI decisions. Hence, not only the bilateral determinants, but also (spatially weighted) third country factors might influence investment behaviour of multinationals.

The removal of customs and other trade barriers lead to a reduction of trade costs within the area. Thus, resident firms may no longer invest in foreign locations. Instead, they can prefer to substitute FDI through exports. On the other hand, RTAs could also raise FDI as firms seek to take advantage of the expanded market and can pursue projects with higher fixed costs. Firms outside the area might increase tariff jumping FDI to take advantage of the larger market (Blonigen, Tomlin and Wilson, 2004). The effects of regional integration are not distributed equally across the area. Member states with strong locational advantages such as an educated labour force or better developed financial markets might attract more FDI, see for example Jaumotte (2004).

\section{$3 \quad$ South-South trade agreements}

RTAs are preferential trade arrangements between countries or groups of countries. The aim is to encourage economic integration and competition in the member states. As such, they can contribute to the catching up process of the developing world. Since RTAs between developed and developing countries (North-South trade) are often driven by cost arguments and the access to natural resources, the focus is on South-South trade, i.e. agreements among emerging market countries.

To obtain comprehensive evidence, the analysis refers to three concrete RTAs, the AGADIR, MERCOSUR and the AFTA agreement. The AGADIR agreement (http://www.agadiragreement. org) aims to create a free trade area between Egypt, Jordan, Morocco and Tunisia since 2004. The treaty is linked to the bilateral agreements of individual countries with the EU as part of 
the Barcelona (1995) process $^{2}$. The rationale behind AGADIR is that integration in Northern Africa is easier to achieve with a core set of countries, and that others can join whenever they are prepared. AGADIR includes the dismantlement of customs, liberalisation of trade including agricultural products, technical assistance to support small and medium sized firms, rules for government procurement and intellectual property rights, common standards and specifications, and mechanisms to resolve conflicts. One specific feature is that AGADIR refers to the EU rules of origin: The EU allows its Mediterranean partners to cumulate value added. According to this principle, preferential treatment holds, independently where of the location of production stages, as long as they are in a partner country. In contrast, the US considers the value added only in the country exporting to the US. The AGADIR region refers to a market of more than 100 million people. GDP is 270 billion USD, measured at constant prices and constant exchange rates. Trade among the signatories is modest, implying that the region is still highly fragmented and cannot be seen as an integrated market. The exports of the member states to each other amount to 3 percent of their total exports. In contrast, almost 45 percent of exports are delivered to the EU. The share seems to be on a declining trend, despite numerous bilateral association agreements.

The MERCOSUR area (http://www.mercosur.int) includes Argentina, Brazil, Paraguay and Uruguay $^{3}$. The aim is to promote free trade and unrestricted movement of labour, capital and products between the member states. The RTA was launched in 1991 by the treaty of Asuncion, and a customs union has been established since 1995. The countries pursue a common trade policy, including the same external tariffs to non-members, and coordinate their macroeconomic policies and governance structures. About 250 million people live within the MERCOSUR boundaries. GDP is 1,5 trillion USD at constant prices and constant exchange rates. Brazil is the largest economy, with shares of 80 percent, both in terms of population and output. Exports within the region amount to 15 percent of the total exports of the member states. The main export markets outside the area are of similar size, with shares of roughly 20 (EU), 10 (US) and 15 (China) percent. FDI inflows into the region increased tremendously after MER-

\footnotetext{
${ }^{2}$ The Barcelona process aims to create a Euro-Mediterranean Free Trade Area with better investment opportunities. To achieve this goal, bilateral association agreements have been signed between the EU and individual Mediterranean partners.

${ }^{3}$ Venezuela joined MERCOSUR as a full member in the mid of 2012. Due to this late accession and the high dependency on natural resources, the country is treated as a non-member in the analysis. In 2012, the membership of Paraguay was suspended, because of the non-democratic dismissal of the president. For convenience, Paraguay is treated as a member country over the whole sample period (1996-2012). Associate and observer countries do not participate in the RTA.
} 
COSUR was launched. However, this development might not be necessarily linked to rising market size and economic integration. In fact, Argentina and Brazil initiated huge privatization programs that may potentially explain the FDI boom. See for example Chudnovsky, Lopez, and Porta (1995) for the details.

The AFTA launched in Singapore 1992 is the trade bloc of the ASEAN economies (http://www. asean.org). Members are Brunei Darussalam, Indonesia, Malaysia, Phillippines, Singapore and Thailand (ASEAN-6) ${ }^{4}$. The RTA aims to increase the competitiveness of ASEAN countries in the global economy by reducing intra-regional tariffs and non-tariff barriers especially on manufactured goods. Actually, tariffs on products listed in the Common Effective Preferential Tariff scheme may not exceed 5 percent. To be subject to the low tariffs, the cumulative value added of ASEAN producers needs to be above 40 percent of the total value of the product. Tariffs on imports may be different according to the national regulations. The area comprises 450 million people, with a real GDP of 1.2 trillion USD. Due to the intensive division of labour in the area, the share of intra-regional exports in total exports (22 percent) is higher than for major trading partners, including China (18). AFTA accounts for 15 percent of output in the whole Southeast Asian region. The small share is due to the fact that large countries like China and India are not members.

-Table 2 about here-

The impact of RTAs on FDI is not obvious (Table 2). For the MENA region, the inflow of foreign capital to GDP has been more visible for the non-AGADIR countries over the last two decades. There is also a substantial acceleration for the AGADIR members at the launch of the RTA. Low initial values in Latin America may reflect large country risk due to the preceding debt crisis. With the turn of the century, however, FDI expanded at a higher rate than GDP, but initially in the non MERCOSUR states. FDI inflows to the AFTA region increased tremendeously over the entire period. But this development may not be caused by the RTA. For example, it can also

\footnotetext{
${ }^{4}$ The founding members are the AFTA countries in the analysis. Other countries like Cambodia, Laos, Myanmar and Vietnam joined the RTA in subsequent years, but they were allowed to be rather flexible in the implementation of the rules of the agreement. In fact, the obligations came into place only recently (2012).
} 
reflect brighter economic perspectives, as the ASEAN countries have become one of the high growth regions in the global economy.

\section{$4 \quad$ The impact of South-South trade on FDI}

Inference on the impact of RTAs on FDI is based on regional panel models estimated seperately for the MENA, Latin America and Southeast Asia countries. The general regression structure is given by

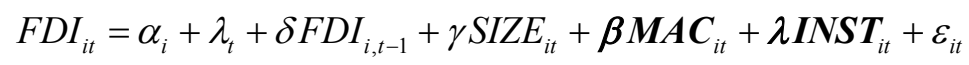

where $\alpha$ is a country fixed effect, $\lambda$ a common time effect and $\varepsilon$ the error term with white noise properties. The indices $i$ and $t$ refer to the country and time series dimension, respectiveIy. The vectors MAC and INST hold the macroeconomic and institutional determinants potentially affecting the FDI decision of multinationals. The coefficients in the rowvectors $\boldsymbol{B}$ and $\boldsymbol{\lambda}$ show the quantitative impact of these variables. The parameter $y$ captures the market size effect related to the RTA. Dynamic effects might be also relevant. They could represent adjustment delays and agglomeration effects, i.e. the successful presence of foreign investors in the host country may trigger further FDI. The parameter $\delta$ denotes the degree of persistence in the adjustment process towards the equilibrium. Because of the dynamic specification $y$ indicates the short run effect of the market size on FDI. The corresponding long run effect is given by $\gamma /(1-\delta)$.

Due to the presence of the lagged dependent variable, the least squares dummy variable is no longer consistent (Baltagi, 2008). The within transformation to remove the country fixed effects will inevitably introduce a correlation with the error term, even if the latter is not serially correlated. The bias declines in $t$, but it can be still substantial even if the time dimension is of moderate size (Judson and Owen, 1999). To deal with this issue, the first difference transformation

$$
\Delta F D I_{i t}=\Delta \lambda_{t}+\delta \Delta F D I_{i, t-1}+\gamma \Delta S I Z E_{i t}+\beta \Delta M A C_{i t}+\lambda \Delta I N S T_{i t}+\Delta \varepsilon_{i t}
$$

wipes out the country fixed effects in a first step. Second, instruments like $F D I_{\mathrm{i}, \mathrm{t}-2}$ or $\triangle F D I_{\mathrm{i}, \mathrm{t}-2}$ are employed to replace the lagged dependent. Since they are correlated with the original regressor, but not with the error term, the IV estimator will be consistent, albeit not efficient. In fact, 
it does not exploit the full set of orthogonality restrictions that exist between the lagged values of the endogenous and the error term. The moving average structure of the disturbances in the differenced model is also neglected. By incorporating this information in a huge matrix of instruments, the Arellano and Bond (1991) GMM estimator can provide efficiency gains. In case of homoscedastic errors, the validity of the instruments can be checked by a Sargan test on overidentifying restrictions. Given that the null hypothesis is not rejected the instruments are appropriate.

The regression framework is based on country individual and RTA related variables, where the latter focus on the market size aspect. In particular, FDI is defined as the FDI stock in the host country, normalized by GDP. To the extent that foreign investments are reversible, stocks are better proxies for FDI activities than their incremental change per period. In addition, variables based on stocks are more robust to temporary distortions. In line with the previous findings, macroeconomic conditions are captured through real per capita GDP and openness to trade, i.e. the trade to GDP ratio, where trade is equal to the sum of exports and imports. For real GDP per capita and openness, RTA related series are also included. They are measured as the gap between these variables at the RTA and the individual country level, and equal to 0 until a country enters the agreement. Due to this setting, an impact of the RTA on FDI can be identified. As the gaps are different across the members, the countries can benefit from the RTA to a different extent.

The regression controls for the real exchange rate, i.e. the deviations from the purchasing power parity condition. They are measured by the bilateral rate of the domestic currency against the US Dollar and based on consumer price indices. Financial depth is captured by domestic credit to the private sector and broad money, both relative to GDP. The institutional conditions are described by government effectiveness, control of corruption, political stability, regulatory quality, rule of law and voice and accountability reflecting the ability of citizens to participate in the political process.

While per capita GDP and the real exchange rate are both measured in logs, the FDI stock to GDP ratio, domestic credit to the private sector, broad money, openness and the two gaps related to per capita income and openness are expressed as a percentage. Institutions are bound within the $[-2.5,+2.5]$ interval, where higher values represent better institutional quality. All variables are obtained from the UNCTAD FDI Statistics and the World Bank, where the World Development Indicators and Worldwide Governance Indicators are employed. Due to 
data availability, evidence is based on annual series for the 1996-2012 period. Since the time series dimension is quite short, the analysis is plagued by multicollinearity problems. To reduce the number of potential regressors, two groups of variables are aggregated in advance. In particular, overall financial depth is defined as the unweighted average of the private credit and broad money ratios to GDP, while the institutional quality is the unweighted average of the six components.

The MENA model includes Algeria, Egypt, Jordan, Morocco, Syria and Yemen. Argentina, Bolivia, Brazil, Chile, Colombia, Ecuador, Paraguay, Peru, Uruguay and Venezuela constitute the Latin American sample. The Asian panel comprises Bangladesh, Brunei Darussalam, Cambodia, China, India, Indonesia, Malaysia, Pakistan, Singapore, Thailand and Vietnam. The selection is mainly driven by data criteria. Due to missing values and structural breaks caused by civil wars and riots, the data are unbalanced. The exclusion of a few years for some countries is indispensable in the MENA region. For example, the Syrian series ends in 2008, as data for the later years are contaminated by the war.

-Figure 2 about here-

Figure 2 displays the potential FDI determinants, both in terms of the entire region and the respective trade agreement. People in the MENA countries receive the lowest real per capita income, both for the entire region and the AGADIR area. Furthermore, the income dynamics appear to be much lower than for the competitors. Due to its weak GDP performance, the region might be less attractive to foreign investors. While Latin American people are richer on average than those in Asia, the ordering is reversed when the focus switches to the RTAs. In fact, large countries with relatively low per capita income like China and India are part of the Asian panel, but not members of the AFTA. It can be seen that Asian economies highly participate in foreign trade, while Latin America is on the lower edge. In addition, financial markets appear to be more advanced in Asia. Like openness, financial markets in the MENA countries seem to be more favourable for investment than in Latin America. It should be noted, however, that the conditions have recently improved in Latin America, while the evolution stagnated for the MENA area. Finally, the institutional setting in MENA countries is much worse for business development when compared to the other regions in the analysis. The backlog is particu- 
larly striking for AGADIR states and has widened during the last years. This may have constituted a decisive obstacle for FDI.

-Table 3 about here-

Table 3 holds the GMM results for the three regions. In addition to the standard FDI determinants, plausible interaction effects are considered as well and are defined as the product of the respective variables. For example, GDP per capita might be important, but only in countries with business friendly institutions. In contrast, previous studies usually did not control for nonlinearities. To increase readability only the significant or almost significant results ( 0.2 level) are reported. The instruments chosen for the Arellano-Bond regressions include the lagged endogenous variable, institutions and macroeconomic series ${ }^{5}$.

According to the results, FDI decisions show a substantial degree of persistence. As the dynamic effect has been often neglected, many previous studies suffer from omitted variable bias. The impact is strong in the Latin American and Southeast Asia. Hence, the size of the coefficient may reflect the success of previous long-oriented policies to attract FDI, especially in the states of the AFTA agreement. The smaller coefficient in the MENA countries points to weaker agglomeration effects, probably because of a lack of policy coordination in largely fragmented markets. Openness and financial depth turn out to be main drivers of FDI in the MENA sample. In contrast, per capita GDP is relevant, but the effect is limited to countries joining the AGADIR treaty. Hence, FDI will be stimulated by a larger market size, and countries with a higher growth potential will receive higher benefits. The significance of the product of the income gap with the institutional setup suggests that FDI may accelerate in countries where the institutional environment is more supportive for business activities.

An income effect is also relevant in the Latin American panel. The membership in the Mercosur area is beneficial to attract foreign capital inflows. Financial markets do not have an impact, despite their interaction with the institutional environment. Hence, Latin American states prof-

\footnotetext{
${ }^{5}$ Because of the presence of the first lag of the endogenous regressor, the minimum delay for the instruments is two years. Potential endogeneity of the macroeconomic regressors is taken into account. For example, the inclusion of lagged instead of contemporaneous regressors do not change the results substantially.
} 
it from deepening financial markets and business friendly institutions. A separate institutional impact may also play a role, although the effect is only significant at the 0.2 level. The negative coefficient of the openness variable indicates that FDI is more directed towards internal markets. Moreover, a real depreciation of the domestic currency against the US Dollar could stimulate FDI activities. Results for Southeast Asia indicate, that per capita income has a positive multiplier, but only in the AFTA countries. While the semielasticity (0.131) seems to be lower than in the other samples, the long run response $(0.131 /(1-0.91)$ is even larger, due to huge agglomeration effects. In addition, FDI related to internal markets is especially relevant for AFTA members, justifying the negative impact of the respective openness variable. Deeper financial markets could trigger FDI, especially when combined with business friendly institutions.

\section{Conclusions}

This paper investigates the impact of South-South trade agreements on FDI in emerging countries using dynamic panel models and GMM estimation techniques. In a comprehensive analysis, the MENA countries are compared to the better performing regions in Latin America and Southeast Asia. Several striking results emerge from the analysis. First, agglomeration effects are the most important variable, but they appear to be less pronounced in the MENA region. This can point to impediments in the coordination of FDI policies within the area. Eventually, the introduction of special economic zones and better transnational policy cooperation might be suitable strategies to foster agglomeration and FDI. Second, RTAs have an impact. In fact, the evidence casts doubts that the often reported market size effect is robust, as a role of income is detected only for the members of the RTA. However, RTAs do not generally improve the attractiveness of the region for foreign investors. This can be seen in the MENA sample, where business-friendly institutions are required for the impulse. Third, financial deepening in the host country is crucial, often again in combination with the framework conditions. In fact, the institutional design may not be relevant per se, but only in terms of its interaction with the macroeconomic determinants. Thus, the implementation of more business-friendly institutions is a challenging task for policymakers. 


\section{References}

Agosin MR, Machado R (2005): Foreign investment in developing countries: Does it crowd in domestic investment? Oxford Development Studies 33, 149-162.

Aitken B, Harrison AE (1999): Do domestic firms benefit from direct foreign investment? Evidence from Venezuela, American Economic Review 89, 605-618.

Aizenman J (1992): Exchange rate flexibility, volatility and patterns of domestic and foreign direct investment, International Monetary Fund Staff Papers 39, 890-922.

Alfaro L, Kalemli-Ozcan S, Sayek S (2009): FDI, productivity and financial development, World Economy 32, 111-135.

Arellano M, Bond S (1991): Some tests of specification for panel data: Monte Carlo evidence and an application to employment equations, Review of Economic Studies 58, 277-297.

Baltagi BH (2008): Econometrics of panel data, 4th ed, Wiley, Chichester, UK.

Baltagi BH, Egger P, Pfaffermayr M (2007): Estimating models of complex FDI: Are there third country effects? Journal of Econometrics 140, 260-281.

Bevan AA, Estrin S (2004): The determinants of foreign direct investment into European transition economies, Journal of Comparative Economics 32, 775-787.

Blomström M, Kokko A (1997): Regional integration and foreign direct investment, NBER Working Paper No 6019.

Blonigen BA (2005): A review of the empirical literature on FDI determinants, NBER Working Paper 11299.

Blonigen BA, Tomlin KK, Wilson WW (2004): Tariff-jumping FDI and domestic firms' profits, Canadian Journal of Economics 37, 656-677.

Borensztein E, De Gregorio J, Lee J-W (1998): How does foreign direct investment affect economic growth? Journal of International Economics 45, 115-135.

Braconier H, Norbaeck P-J, Urban D (2005): Multinational enterprises and wage costs: Vertical FDI revisited, Journal of International Economics 67, 446-470.

Chakrabarti A (2001): The determinants of foreign direct investment: Sensitivity analyses of cross-country regressions, Kyklos 54, 89-112. 
Chudnovsky D, Lopez A, Porta F (1995): New foreign direct investment in Argentina: Privatization, the domestic market and regional integration, in Agosin MR (ed): Foreign direct investment in Latin America, Inter-American Development Bank, Washington.

De Mello L (1997): Foreign direct investment in developing countries and growth: A selective survey, Journal of Development Studies 34, 1-34.

Drabek Z, Payne W (2001): The impact of transparency on foreign direct investment, WTO Staff Working Paper ERAD-99-02.

Dunning JH, Lundan SM (2008): Multinational enterprises and the global economy, 2nd ed, Edward Elgar, Cheltenham.

Froot K, Stein J (1991): Exchange rates and foreign direct investment: An imperfect capital markets approach, Quarterly Journal of Economics 196, 1191-1217.

Globerman S, Shapiro D (2003): Governance infrastructure and US foreign direct investment Journal of International Business Studies 34, 19-39.

Habib M, Zurawicki L (2002): Corruption and foreign direct investment, Journal of International Business Studies 33, 291-307.

Jaumotte F (2004): Foreign direct investment and regional trade agreements: The market size effect revisited, IMF Working Paper WP04/206.

Judson RA, Owen AL (1999): Estimating dynamic panel data models. A guide for macroeconomists, Economic Letters 65, 9-15.

Klein MW, Rosengren ES (1994): The real exchange rate and foreign direct investment in the United States: Relative wealth vs. relative wage effects, Journal of International Economics 36, 373-389.

Kumar N (2002): Globalization and the quality of foreign direct investment, Oxford, Oxford University Press.

Lee J-Y, Mansfield E (1996): Intellectual property protection and US foreign direct investment, Review of Economics and Statistics 78, 181-186.

Luo Y (2009): Political risk and country risk in international business. Concepts and measures, Rugman AM (ed), The Oxford Handbook of International Business. Oxford University Press, 740-764. 
Markusen JR, Maskus KE (2002): Discriminating among alternative theories of the multinational enterprise, Review of International Economics 10, 694-707.

Markusen JR, Venables AJ (1997): Foreign direct investment as a catalyst for industrial development, NBER Working Paper 624.

Navaretti GB, Venables AJ (2006): Multinational firms in the world economy, Princeton University Press, Princeton.

Noorbakhsh F, Paloni A, Yousef A (2001): Human capital and FDI to developing countries: New empirical evidence, World Development 29, 1593-1610.

Wei SJ (2000): How taxing is corruption on international investors? Review of Economics and Statistics 82, 1-11.

Wheeler D, Mody A (1992): International investment location decisions. The case of US firms, Journal of International Economics 33, 57-76. 
Figure 1: FDI into emerging market countries

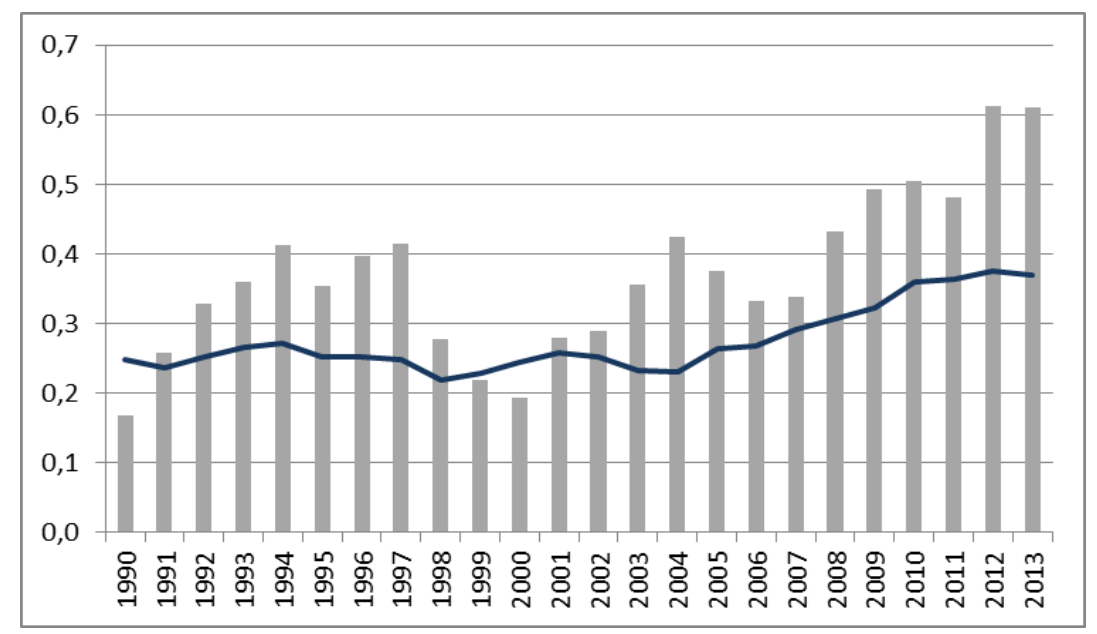

Note: Percentage of global FDI. Shaded area FDI inflows, line FDI stocks. Unctad FDI database. 
Figure 2: Potential FDI determinants as regional (left) and RTA averages

Real per capita income
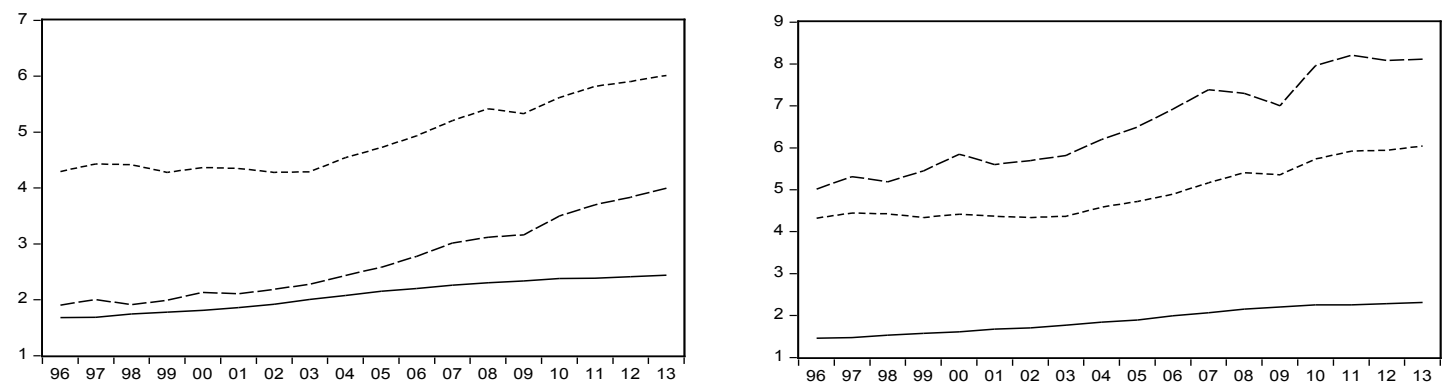

Openness to trade
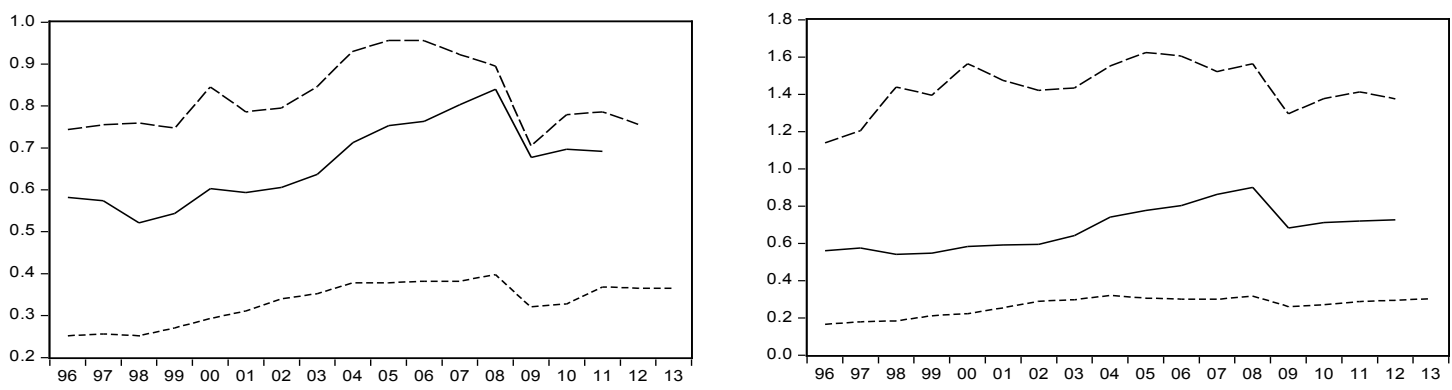

Financial depth
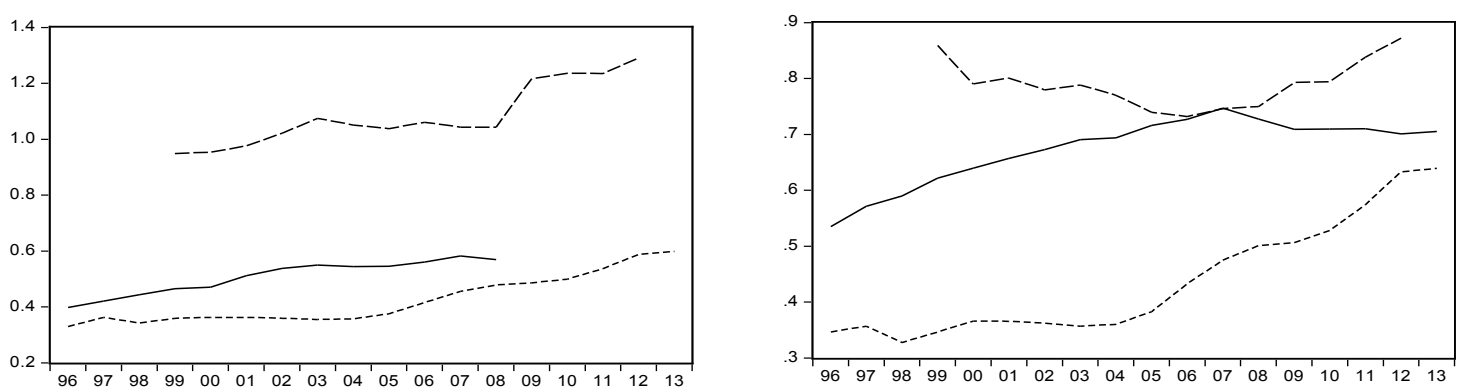

Institutions
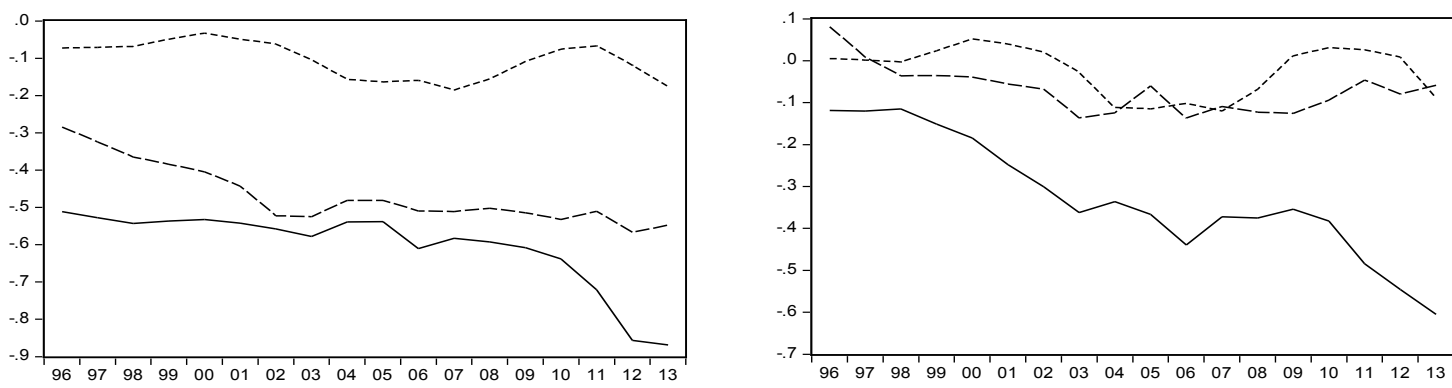

Note: GDP weights for aggregation. Real per capita GDP in constant 1000 USD and constant exchange rates with 2005 as the base year. Openness and financial market development as percentages, institutions in [-2.5, +2.5]. Financial market development and the institutional design correspond to the unweighted average of the respective two and six individual indicators. Line Mena countries, punctated line Latin American countries, dashed line Asian countries. 
Table 1: FDI stock to GDP in emerging markets

\begin{tabular}{|l|c|c|c|c|c|c|}
\hline Region & 1995 & 2000 & 2005 & 2009 & 2011 & 2012 \\
\hline MENA & 16.1 & 21.0 & 28.5 & 36.9 & 35.2 & 34.3 \\
\hline Latin America & 9.1 & 23.1 & 26.3 & 27.1 & 28.6 & 31.9 \\
\hline Southeast Asia & 21.4 & 34.0 & 28.8 & 29.6 & 27.6 & 29.1 \\
\hline
\end{tabular}

Note: UNCTAD FDI database. 
Table 2: FDI stock to GDP for RTA members and non member states

\begin{tabular}{|l|c|c|c|}
\hline & MENA & Latin America & Southeast Asia \\
\hline 1995 & $24.9 \mid 5.7$ & $7.4 \mid 14.5$ & $21.2 \mid 31.0$ \\
\hline 2000 & $26.7 \mid 19.3$ & $20.1 \mid 30.7$ & $41.6 \mid 32.2$ \\
\hline 2005 & $40.1 \mid 21.6$ & $22.0 \mid 34.9$ & $47.9 \mid 24.7$ \\
\hline 2012 & $42.9 \mid 27.6$ & $31.0 \mid 33.8$ & $64.8 \mid 22.6$ \\
\hline
\end{tabular}

Note: Left (right) entry: FDI stock to GDP ratio for RTA (non RTA) countries. UNCTAD FDI statistics. 
Table 3: FDI regressions

\begin{tabular}{|c|c|c|c|}
\hline & MENA & Latin America & Southeast Asia \\
\hline FDI(-1) & $0.464(0.063)$ & $0.735(0.049)$ & $0.910(0.029)$ \\
\hline Per capita income & & $0.053(0.044)$ & \\
\hline Income gap & $0.163(0.044)$ & $0.180(0.090)$ & $0.131(0.065)$ \\
\hline Openness & $0.118(0.067)$ & $-0.178(0.061)$ & \\
\hline Openness gap & & & $-0.067(0.040)$ \\
\hline Financial depth & $0.275(0.067)$ & & $0.221(0.059)$ \\
\hline Institutions & & $0.065(0.054)$ & \\
\hline Institutions*Income & $0.231(0.073)$ & & \\
\hline Institutions*FinDepth & & $0.208(0.102)$ & $0.117(0.059)$ \\
\hline PPP & & $0.034(0.018)$ & \\
\hline Constant & $-0.106(0.054)$ & $-0.126(0.123)$ & -0.115 \\
\hline Sargan $p$-value & 0.122 & 0.134 & 0.111 \\
\hline
\end{tabular}

Note: GMM estimation of dynamic panel model according to Arellano and Bond (1991). 